\title{
THE ZERO TOLERANCE APPROACH TO VIOLENCE AGAINST WOMEN
}

\section{LANDON JENNINGS}

SOC 228 - SOCIOLOGY OF CRIMINAL JUSTICE

Violence against women is an endemic in North America (Drumbl, 1995). Specifically, "about one in ten married women experience battering each year, in Canada" (Macleod, 1980, p. 67). In 1986, in an attempt to address this issue, the criminal justice system implemented a zero tolerance approach (also known as mandatory charging) to cases of domestic violence (Drumbl, 1995). Advocates believe this approach is needed, whereas others believe that mandatory charging is too harsh.

Regardless, abuse of female partners is still prevalent in our society, as the one in ten statistic still stands (Department of Justice, 2005). Women are abused every day, and many silently sit back until it is too late (Drumbl, 1995). For example, in Singh (2010), the author discusses her encounter with victim of domestic violence named Cynthia. The author came across her working at the Victim Witness Assistant Program in an Ontario courthouse, where she followed her case closely (Singh, 2010). Though the coordinators in this program did their best for Cynthia, she became part of the ongoing statistic of a woman, whose voice was silent as her husband battered and later murdered her. As Singh (2010) explains, Cynthia's death perfectly embodies the array of complexities that domestic violence incidents pose for the criminal justice system. Seeing the reality, the attempt to prevent harm through mandatory charging is important to understand. However, to do so, it is an imperative to ensure that people are educated on the Laws' purpose. This will not only ensure people understand the function, but will also allow for informed discussion about reforms to possibly better mitigate abuse. 
The zero tolerance approach emerged in an attempt by advocates to take violence against woman more seriously (Martin \& Mosher, 1995, p. 18). Supporters believed that "if charges were laid, when an assault occurred, offenders would be punished, and individual victims of violence would be protected and woman would benefit" (Martin \& Mosher, 1995, p. 18). The belief was that the law was needed to ensure equality of women by treating abuse just like any other crime (Singh, 2010, p. 340). Also, being more punitive would send the message that domestic violence was not tolerated (Martin et al., 1995).

Prior to the adoption of this approach, officers were able to decide how to deal with instances of abuse (Singh, 2010). However, when mandatory charging came into effect, police officers were "directed to lay charges in all instances of domestic violence where there is evidence of assault, regardless if the victim wants to press a charge or not" (Singh, 2010, p. 341). This was to prevent officers from making inappropriate decisions, and further reiterates the goal of the approach, which was to treat abuse as a criminal matter.

Another impetus for implementing this tough on crime approach to dealing with abuse stemmed from a history of systemic neglect (Singh, 2012). Though laws prohibiting violence against woman existed since the early 1900's, they were rarely utilized. As explained by Hilton (1988), "part of the difficulty (with evoking these laws) lies within the traditional definitions of abuse, as it has been characterized as a private matter, better dealt with in the home" (p. 314). Seeing this, many were reluctant to use existing laws and respond to abuse as a social problem.

The momentum to bring to light the prevalence of woman beating, and attempt to make abuse a social matter, occurred in the 1980's (Drumbl, 1995). The critical factor in change was the effort of feminist activists, such as Linda Macleod (Hilton, 1988). In her study, Wife Battering in Canada: The Vicious Circle (1980), she illustrated the frequency of female partner abuse in 
Canada and showed the inadequacy of current policies in preventing harm to victims (Macleod, 1980). Specifically, she illustrated that 500,000 females were battered each year, yet studies indicated, "in $45 \%$ of cases where police presence was requested, advice was the response given" (Macleod, 1980, p.108). She concluded that by not being punitive, the legal system was supporting the "powerlessness of woman and accepting battering" (Macleod, 1980, p. 42). This led to the formation of a parliamentary committee, which eventually led to the suggestion of a zero tolerance approach (Singh, 2010).

Another Influential figure to this movement was the London Coordinating Committee on Family Violence, formed after Macleod's study in 1981(Drumbl, 1995). This committee recommended that police discretion be removed in abuse cases, as they were placing charges in less than 5\% of cases (Singh, 2012). London, Ontario thus became the first city to implement the zero tolerance policy, and from its implementation saw a significant increase in domestic violence calls (Drumbl, 1995). Specifically, research shows that "several years after implementing this policy, the number of domestic violence calls rose by 2500\%” (Drumbl, 1995, p. 227). By 1986 this approach was implemented to other Canadian jurisdictions (Singh, 2012). Currently, all Canadian jurisdictions follow the zero tolerance policy (Singh, 2010).

The implementation of zero tolerance has affected victims of abuse, perpetrators, and the response of law enforcement. Generally, this approach improves victim rights and successfully conveys the message that violence is unacceptable (Martin et al., 1995). Despite this, there are shortcomings (Drumbl, 1995). Specifically, "more than $75 \%$ of abuse incidents involve woman of colour," yet they are the most reluctant to call for help since they tend to experience negative consequences of the approach (Drumbl, 1995, p. 335). For instance, some minority woman may experience difficulty with language barriers when seeking aid from the police, along with the 
detrimental impact on family income that these woman experience upon their husband's' incarceration.

For example, African-American woman are more prone to excuse their husband's behaviour due to the negative consequences they have experienced (Drumbl, 1995). As illustrated by in Drumbl (1995):

"all battered woman have the tendency to blame themselves and excuse their husband's behaviour...but this tendency is more marked in African-American woman, who know only too well that that in this society, life is harder for black men than for white men" (p. 235).

Additionally, the loss of financial support is another major consequence of zero tolerance (Singh, 2012). As studied by Martin and Mosher (1995), Unkept Promises: Experiences of Immigrant Women With the Neo-Criminalization of Wife Abuse, this criminal justice intervention causes more harm than good. Many Canadian women are dependent on their husbands, particularly financially (Singh, 2010). Thus, incarceration causes them more harm since women are left to figure out how to cover daily expenses for their families.

This hardship (dependency) causes more problems for immigrant woman. Since husbands usually sponsor their immigrant wives to be in the country, the immigrant woman often faces the risk of deportation in the event of their husband's arrest (Martin et al., 1995). This threat leaves victims of abuse less likely to call the police. For instance, Martin and Mosher (1995) found that "husbands were able to terrorize immigrant wives with the fear of deportation, so many ignored abuse" (p. 26). Thus, zero tolerance sometimes causes more harm than good.

Despite the hardship some face in regards to the zero tolerance approach, advocates still believe this is the best method to prevent harm. For instance, Liberal feminists argue that despite 
the shortcomings, this policy is essential to send the message the abuse is unacceptable (Singh, 2012). As argued by activist Linda Macleod, putting a law in place that is punitive sends a clear message and "shapes the values of society" which benefits woman as a whole (Singh, 2010 p. 43).

On the contrary, some disagree that zero tolerance helps all woman, such as immigrants, and believe that this criminal justice response goes against empowerment model (Singh, 2010). Though the intent of this law is good, sometimes removing the discretion of victims causes more harm to victims. This was illustrated in Martin and Mosher (1995), as many immigrant women experienced difficulty once their husbands' were charged with domestic abuse. With any domestic violence call for immigrant women, there is a possibility that her citizenship may be taken from her, and with this, her children, family, and dignity. Additionally, removing discretion aids in oppression of woman (Singh, 2012). By not having a say in the outcome of her abuse, opponents argue woman lose their voice. As illustrated in studying cases in Landau (2000), a victim stated: "they did not listen to me...show a little respect. They never asked me what I wanted, they just proceeded anyways" (Singh, 2010, p. 347). Thus, critics argue that zero tolerance approach is harmful.

All in all, female partner abuse is a serious and complex issue. With the success of Liberal feminists advocating to be tough on spousal abuse, the reality of abuse is no longer hidden behind closed doors (Drumbl, 1995). Despite this success, it is an on ongoing debate as to whether this policy is the best to prevent harm and support victim rights. Currently, other avenues are being explored to determine the future direction of this criminal justice response. For example, treatment of abusers outside the justice system is being considered. Advocates argue this will reduce harm since the abuser will receive treatment and the victim will not face the challenges (i.e. economic) that may come with incarceration (Drumbl, 1995). Despite this, the fear is that not being punitive 
will send the wrong message and result in an increase in abuse incidents. Thus, though zero tolerance may not be the best measure, female partner abuse is an important issue to understand since it is an ongoing issue, experienced by many women in society. 


\section{References}

Department of Justice Canada. (2005). Final Report of the Ad-Hoc FederalProvincial-Territorial Working Group Reviewing Spousal Abuse Policies and Legislation. Retrieved from: http://publications.gc.ca/collections/Collection/J2-1932002E.pdf

Drumbl, A. M. (1995). Civil, Constitutional and Criminal Justice Responses to Female Partner Abuse: Proposals for Reform. Canadian Journal of Family Law, 12 (1). Retrieved from: http://www.heinonline.org.proxy.lib.uwaterloo.ca/HOL/Page?page=115\&handle=hein.jo urnals $\% 2$ Fcajfl12\&collection=journals

Hilton, Z. N. (1988). One in Ten: The Struggle and Disempowerment of the Battered Woman's Movement. Canadian Journal of Family Law, 7 (2). Retrieved from: http://www.heinonline.org.proxy.lib.uwaterloo.ca/HOL/Page?page=313\&handle=hein.jo urnals\%2Fcajfl7\&collection=journals

Macleod, L. (1980). Wife Battering in Canada: the Vicious Circle. Ottawa, Ontario: Canadian Advisory Counsel on the Status of Woman.

Martin, D.L., \& Mosher, J. (1995). Unkept promises: Experiences of Immigrant Woman with the Neo-Criminalization of Wife Abuse. Canadian Journal of Woman and the Law, 8 (1). Retrieved from:

http://www.heinonline.org.proxy.lib.uwaterloo.ca/HOL/Page?page=3\&handle=hein.journ als $\% 2$ Fcajwol $8 \&$ collection=journals

Singh, R. (2010). In-between the system and the Margins: Community Organizations, Mandatory Charging and Immigrant Victims of Abuse. Canadian Journal of Sociology, 35 (1). Retrieved from: https://ejournals.library.ualberta.ca/index.php/CJS/article/view/6786/6463

Singh, R. (2012). Domestic Violence and Mandatory Criminal Justice Interventions: Re-Evaluating the Zero Tolerance Approach. In Roberts, V.J., and Grossman, G.M., (eds). Criminal Justice in Canada (338-352). Toronto Ontario, Nelson Education. 
